\title{
Coagulation Studies in Haemolytic Uraemic Syndrome
}

\author{
M. L. N. WILLOUGHBY, ANNA V. MURPHY, SHEILA McMORRIS, and \\ F. G. JEWELL \\ From the Royal Hospital for Sick Children, Glasgow
}

\begin{abstract}
Willoughby, M. L. N., Murphy, A. V., McMorris, S., and Jewell, F. G. (1972). Archives of Disease in Childhood, 47, 766. Coagulation studies in haemolytic uraemic syndrome. Serial coagulation investigations were performed in 4 children with the haemolytic uraemic syndrome treated with heparin by continuous infusion. 2 anuric patients showed consumption of factor $\mathrm{V}$ and fibrinogen early in the disease, with thrombocytopenia and raised fibrin degradation products. These changes regressed during heparin therapy and renal function fully recovered in both patients. A third patient with a mild form of the disease, normal urinary output, and only borderline thrombocytopenia did not develop demonstrable depletion of factor $\mathrm{V}$ or fibrinogen. In a further patient a secondary 'wave' of consumption of platelets and perhaps fibrinogen was seen late in the course of the disease. These findings confirmed the occurrence of a consumptive coagulopathy in severe cases of haemolytic uraemic syndrome.
\end{abstract}

Microangiopathic haemolytic anaemia is recognized by the development of fragmented 'burr' erythrocytes in the blood film together with a falling haemoglobin level and usually a falling platelet count. These are constant findings in the haemolytic uraemic syndrome (HUS) of childhood (Brain, 1969), and there is much experimental and pathological evidence to suggest that they are due to the deposition of fibrin within arterioles and capillaries, resulting in damage to the circulating red cells and trapping of the platelets (Brain, Dacie, and Hourihane, 1962; Brain and Hourihane, 1967; Brain et al., 1968; Rubenberg et al., 1968; Bull et al., 1968).

Whether these changes are due to purely local fibrin deposition with little systemic changes in the coagulation system, or whether they represent disseminated intravascular coagulation (DIC) with consumption of the circulating clotting factors ('consumptive coagulopathy'), has remained debatable. Hammond and Lieberman (1970) in a recent review of HUS state, 'the characteristic pattern of consumption of coagulation factors, which is seen in disseminated intravascular coagulation has not yet been seen clearly in HUS, since few systematic studies have been achieved'. In an annotation on the same subject Lanzkowsky and McCrory (1967) comment, 'In order to achieve a

Received 5 May 1972. clearer understanding of the role of DIC, there is a great need for sequential investigation of coagulation factors to be carried out in all cases.' Of the two most recent coagulation studies in this disease, one has favoured (Sanchez Avalos et al., 1970) and the other failed to confirm a consumptive coagulopathy (Katz et al., 1971).

We have performed serial coagulation investigations before and after heparin therapy in 4 children with HUS in an effort to throw more light on this problem.

\section{Methods}

Standard haematological methods were performed as described by Dacie and Lewis (1963), and the platelet counts by the method of Brecher and Cronkite (1950). Venous blood was collected into a silicone tube containing 1 part of $3.8 \%$ sodium citrate to 9 parts of blood. This was immediately placed in an ice and water mixture in a vacuum flask for transfer to the laboratory. The plasma was separated at $1{ }^{\circ} \mathrm{C}$ in a refrigerated centrifuge at $1500 \mathrm{~g}$ for 20 minutes. Thereafter, it was stored in aliquots at $-30{ }^{\circ} \mathrm{C}$ for subsequent batchwise assay of individual coagulation factors. Fibrinogen and plasminogen were estimated by the method of Alkjaersig, Fletcher, and Sherry (1959), factor VIII assays were performed by the method of Hardisty and MacPherson (1962), and factor V assays by the method of Stefanini (1950). For estimation of fibrin degradation products (FDPs) $3 \mathrm{ml}$ venous blood was placed in glass tubes containing 300 units Trasylol and incubated for 18 hours at $37^{\circ} \mathrm{C}$ after clotting. The separated serum was 
stored at $-30{ }^{\circ} \mathrm{C}$ until assay by the tanned red cell technique of Merskey, Kleiner, and Johnson (1966).

\section{Case Histories}

Case 1. At the age of 9 years she was investigated for pallor at another hospital and found to have $\mathrm{Hb} 5$ $\mathrm{g} / 100 \mathrm{ml}$ and a reticulocyte count of $52 \%$. The blood urea at the start of this illness was $315 \mathrm{mg} / 100 \mathrm{ml}$ and had fallen to $53 \mathrm{mg} / 100 \mathrm{ml}$ on discharge.

One year later, she was admitted to the same hospital with increasing pallor and vomiting after an upper respiratory infection 6 days previously. On examination she was pale with scattered petechiae. BP was 130/70 $\mathrm{mmHg}$. Urine contained protein and $\mathrm{RBCs}, \mathrm{Hb}$ was $7 \cdot 6 \mathrm{~g} / 100 \mathrm{ml}$, platelets $165,000 / \mathrm{mm}^{3}$, and reticulocytes $8 \%$. Blood urea on admission was $310 \mathrm{mg} / 100 \mathrm{ml}$. On the assumption that she had recurrent haemolytic anaemia, prednisolone was started at a dose of $45 \mathrm{mg}$ per day. She was transferred to this hospital, 6 days later. Peritoneal dialysis was begun 3 days after this when blood urea had risen to $330 \mathrm{mg} / 100 \mathrm{ml}$ and the steroids were stopped. Dialysis was continued for 27 hours, lowering the blood urea to $99 \mathrm{mg} / 100 \mathrm{ml}$. For the next 17 days her condition remained static with the blood urea remaining close to $100 \mathrm{mg} / 100 \mathrm{ml}$, and her BP well controlled. IV heparin was administered as shown in Fig. 1. She improved clinically but the BP rose steadily. There was little response to guanethidine and reserpine and she began having generalized grand mal convulsions with a BP of $150 / 110$ $\mathrm{mmHg}$ and died without regaining consciousness about 6 weeks after the onset of her illness.

At necropsy, the appearance of each kidney was similar, with a proportion of normal glomeruli and some totally sclerosed. In between the two extremes there were numerous glomeruli showing either capillary dilatation with engorgement, or capillary thrombi with ischaemic damage to endothelial nuclei. There were early arteriolar hypertensive changes.

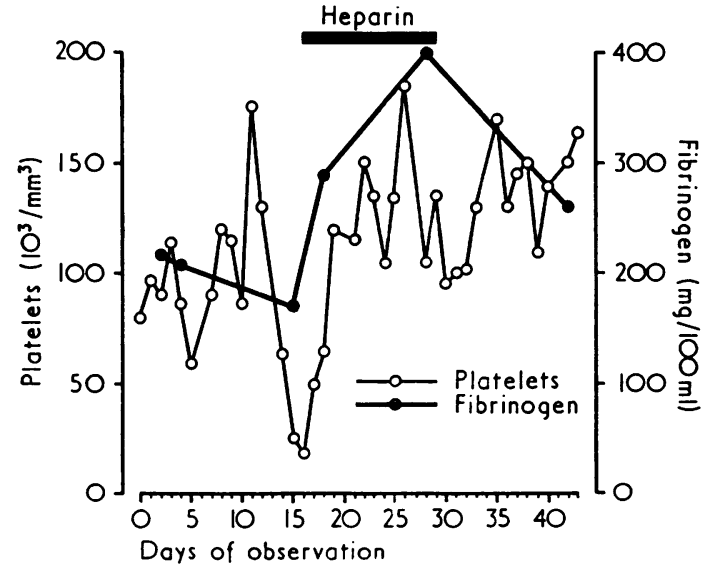

Fig. 1.-Case 1. Serial platelet counts and fibrinogen levels. Body wt. $21.7 \mathrm{~kg}$. Initial heparin dose 500 units/hour, later reduced to 350 units/hour.
Case 2. A 4-year-old boy was admitted with abdominal pain and vomiting and anuria for 24 hours. He was drowsy and pale with scattered petechiae. BP was $130 / 90 \mathrm{mmHg}$. Blood urea was $352 \mathrm{mg} / 100 \mathrm{ml}$, Hb $7.8 \mathrm{~g} / 100 \mathrm{ml}$, platelets $40,000 / \mathrm{mm}^{3}$, and a blood film showed numerous burr cells. The diagnosis of HUS was made and since the child remained anuric with a rising blood urea and a falling $\mathrm{Hb}$, peritoneal dialysis was started about 24 hours after admission. Intravenous heparin infusion was given $25 \mathrm{U} / \mathrm{kg}$ per $\mathrm{hr}$, maintaining the capillary clotting time between 4 and 6 minutes. Peritoneal dialysis was continued for 72 hours, the blood urea then being $138 \mathrm{mg} / 100 \mathrm{ml}$. Intravenous heparin was discontinued after 60 hours because of the development of a haematoma of his right thigh, consequent upon an intramuscular injection.

After dialysis, there was a gradual rise in urinary output. The platelets rose to normal and $\mathrm{Hb}$ remained around $10 \mathrm{~g} / 100 \mathrm{ml}$. Spherocytes and fragmented RBC persisted in the blood film for more than 6 weeks after his illness.

One year later he was well, with normal $\mathrm{Hb}$, blood urea, and urine.

Case 3. An 8-year-old girl was admitted complaining of abdominal pain, anorexia, and weakness. 6 days before this she had diarrhoea lasting 3 days and had passed no urine from then until her admission. On examination she was an ill child with pallor and icterus but no ecchymoses. Her hydration was normal and she was normotensive. She had generalized abdominal tenderness but no guarding. $\mathrm{Hb}$ was $10 \mathrm{~g} / 100 \mathrm{ml}$, platelets $10,000 / \mathrm{mm}^{3}$, and burr cells and spherocytes were present on a blood film. Blood urea was 486 $\mathrm{mg} / 100 \mathrm{ml}$. Urine passed 24 hours after admission contained RBCs, and hyaline, granular, and cellular casts.

A diagnosis of HUS was made and peritoneal dialysis started. Heparin was given in an initial dosage of 25 $\mathrm{U} / \mathrm{kg}$ per $\mathrm{hr}$ by continuous intravenous infusion. Peritoneal dialysis was continued for 48 hours with improvement in the child's general condition and a fall in the blood urea to $135 \mathrm{mg} / 100 \mathrm{ml}$. 3 days after dialysis she had a generalized grand mal seizure from which she recovered well with no obvious neurological deficit. After this there was an increase in urinary output and a fall in blood urea levels to within normal limits. Heparin therapy was discontinued on the 14th day of the illness and she was discharged home well 3 weeks later. She has been seen for follow-up and was well with normal renal function as judged by creatinine clearance and no hypertension 14 months after her illness.

Case 4. A boy, aged 1 year 7 months was admitted with a history of diarrhoea and vomiting for 10 days. $\mathrm{Hb}$ was $4.5 \mathrm{~g} / 100 \mathrm{ml}$, platelets $134,000 / \mathrm{mm}^{3}$, and blood urea $320 \mathrm{mg} / 100 \mathrm{ml}$. The provisional diagnosis of HUS was made and he was transferred to this hospital.

He was pale and ill. There were no petachiae. BP was $130 / 80 \mathrm{mmHg}$. Urine contained protein and RBCs. 


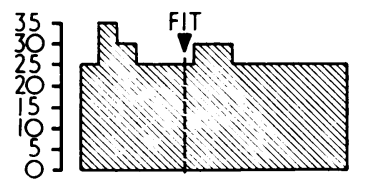

Heparin $(\mathrm{U} / \mathrm{kg} / \mathrm{hr})$
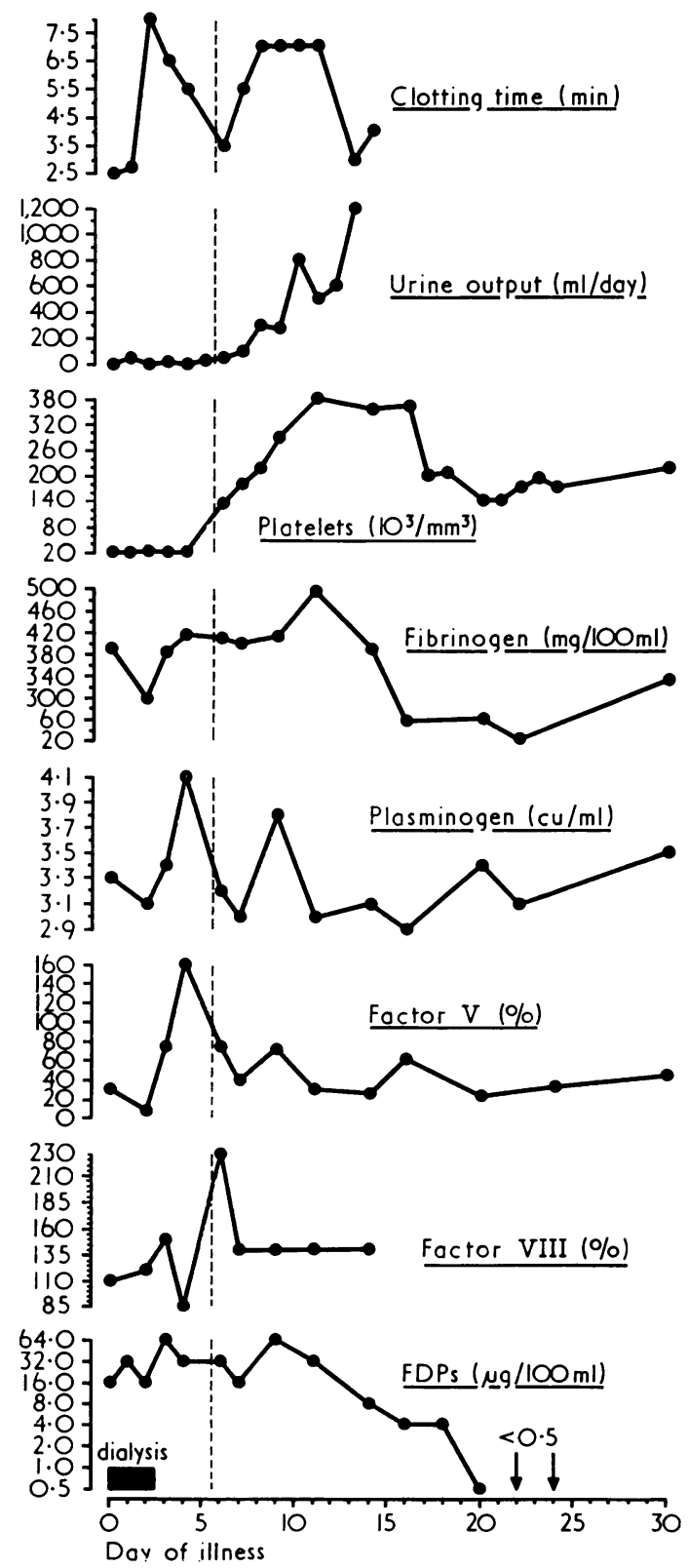

FIG. 2.-Serial platelet counts, coagulation factors, and urine output in a girl of 8 with HUS (Case 3). Wt 18.4 kg. Note: Plasminogen was measured in casein units/ml.
Blood urea was $418 \mathrm{mg} / 100 \mathrm{ml}$. Peritoneal dialysis was started and heparin was given by continuous intravenous infusion at the rate of $25 \mathrm{U} / \mathrm{kg}$ per hr. Urinary output remained around $400 \mathrm{ml} / 24$ hours for the 3 days after admission. Peritoneal dialysis was carried out for a period of 30 hours, lowering the blood urea to 102 $\mathrm{mg} / 100 \mathrm{ml}$. Over the first 5 days there was gradual increase in urinary putput, with fall in blood urea to within normal limits. Heparin was discontinued after 5 days. The child was well with normal renal function and normal blood pressure 4 months after his illness.

\section{Results}

Fig. 1 shows serial platelet and fibrinogen values in Case 1. Heparin therapy was instituted after a progressive fall in platelet count and was followed by a rise in platelet count and a probably significant rise in fibrinogen level.

Table I gives the coagulation results in Case 2 both at diagnosis and after heparin therapy. Fibrinogen and factor $\mathrm{V}$ were pathologically low at diagnosis, but rose later. Fibrin degradation products (FDPs) were initially raised but fell later. Subsequently, the platelet count rose to normal and the patient fully recovered.

Fig. 2 shows the sequential changes in coagulation factors, platelet count, and urine output in Case 3. During the initial stages factor $\mathrm{V}$ was low and falling; FDPs were raised. Changes in fibrinogen and plasminogen paralleled factor $\mathrm{V}$. After an increase in heparin dose to $35 \mathrm{U} / \mathrm{kg}$ per $\mathrm{hr}$ on day 2 these changes appeared to be reversed and followed by a rebound rise of factor $\mathrm{V}$, fibrinogen, and factor VIII (AHG). After the response of coagulation factors there was a rise in platelet count, a return of urine flow, and a gradual fall in FDPs. The patient fully recovered.

In Case 4 without thrombocytopenia the fibrinogen was $280 \mathrm{mg} / 100 \mathrm{ml}$, factor V $145 \%$, factor VIII $140 \%$, and plasminogen 4.9 casein units $/ \mathrm{ml}$. There were no significant changes in these values over the succeeding 8 days. The FDPs, however, were raised to $160 \mu \mathrm{g} / \mathrm{ml}$ at diagnosis and progressively fell to $20 \mu \mathrm{g} / \mathrm{ml}$ over the next 4 days. He had a 'hig'l output' type of renal failure and fully recovered.

\section{Discussion}

Evidence of a consumptive coagulopathy. The findings in Case 2 provide what is probably the clearest evidence yet reported of a consumptive coagulopathy during the early stage of HUS. The pathologically low 'consumable' coagulation factors $\mathrm{V}$ and fibrinogen $(17 \%$ and $61 \mathrm{mg} / 100 \mathrm{ml})$ in association with raised FDPs $(160 \mu \mathrm{g} / \mathrm{ml})$ at the time of diagnosis indicate a severe degree of intravascular coagulation and fibrin deposition. 
TABLE I

Coagulation Results in Case 2

\begin{tabular}{|c|c|c|c|c|c|c|}
\hline & $\begin{array}{c}\text { Fibrinogen } \\
(\mathrm{mg} / 100 \mathrm{ml})\end{array}$ & $\begin{array}{c}\text { Factor V } \\
(\%)\end{array}$ & $\begin{array}{c}\text { Factor VIII } \\
(\%)\end{array}$ & $\begin{array}{c}\text { FDPs } \\
(\mu \mathrm{g} / \mathrm{ml})\end{array}$ & $\begin{array}{l}\text { Platelets } \\
\text { (per } \mathrm{mm}^{3} \text { ) }\end{array}$ & $\begin{array}{c}\text { Plasminogen } \\
\text { (casein units } / \mathrm{ml} \text { ) }\end{array}$ \\
\hline $\begin{array}{l}\text { Day } 1 \\
\text { Day } 3\end{array}$ & $\begin{array}{r}61 \\
195\end{array}$ & $\begin{array}{l}17 \\
40\end{array}$ & $\begin{array}{l}115 \\
155\end{array}$ & $\begin{array}{r}160 \\
40\end{array}$ & $\begin{array}{l}40,000 \\
38,000\end{array}$ & $\begin{array}{l}2 \cdot 9 \\
2 \cdot 9\end{array}$ \\
\hline Normal values & $300+$ & $50-200$ & $50-200$ & $0-20$ & $150,000+$ & $3 \cdot 0+$ \\
\hline
\end{tabular}

The microangiopathic haemolytic anaemia and low plasminogen during this period are similarly consistent with intravascular coagulation. The coagulation data for this patient (Table I) would widely be accepted as diagnostic of DIC (Corrigan, Ray, and May, 1968; Deykin, 1970; Hathaway, 1970). Likewise the initial and sequential findings in Case 3 provide similar evidence of intravascular coagulation (Fig. 2). The 'rebound' rises of factors V and VIII to around $200 \%$ after heparin are particularly characteristic of preceding DIC (Hathaway, 1970).

The particular point which Case 1 showed was the 'wave' of platelet, and perhaps fibrinogen, consumption occurring at some time after the initial diagnosis of HUS, and their response to heparin. She died later of hypertensive encephalopathy and the necropsy showed microthrombi in the glomerular capillaries. Heparin had been stopped some weeks before death.

Case 4 did not show a consumption of coagulation factors. Clinically he was also the mildest affected of our 4 patients, never suffering from anuria or oliguria. The platelet count was $130,000 / \mathrm{mm}^{3}$ at diagnosis, and the lowest subsequent count was 82,000 compared to nadirs of $18,000,38,000$, and 22,000 in Cases 1, 2, and 3, respectively. Raised FDPs were the only evidence of intravascular coagulation. It seems likely that in parallel with this patient's milder renal manifestations there was also a milder degree of intravascular coagulation, without actual depletion of circulating coagulation factors. It is known, for instance, that increased catabolism of fibrinogen can occur in patients with microangiopathic haemolytic anaemia without actual lowering of the circulating fibrinogen level (Baker et al., 1968).

Comparison with previous coagulation studies in HUS. Table II lists previous observations of the coagulation system in children with HUS. Many of the findings are suggestive of consumptive coagulopathy but few are conclusive. Sequential studies from an early stage of the disease have been relatively lacking. The series of 16 infants reported by Katz et al. (1971) included only 5 with anuria and only 2 with platelet counts below $50,000 / \mathrm{mm}^{3}$. The isolated coagulation

TABLE II

Published Data Relevant to Consumption Coagulopathy in Childhood HUS

\begin{tabular}{|c|c|c|c|c|c|}
\hline Authors & $\begin{array}{c}\text { Fibrinogen } \\
(\mathrm{mg} / 100 \mathrm{ml})\end{array}$ & $\begin{array}{c}\text { Factor V } \\
(\%)\end{array}$ & $\begin{array}{c}\text { Factor VIII } \\
(\%)\end{array}$ & FDPs & $\begin{array}{l}\text { Platelet Rise } \\
\text { After Heparin }\end{array}$ \\
\hline $\begin{array}{l}\text { Sanchez Avalos et al. }(1970)^{\star} \\
\text { Katz et al. }(1971)^{\star} \\
\text { Gilchrist } \text { et al. }(1969)^{\star} \\
\text { Monnens and Schretlen (1967) } \\
\text { Uttley (1970) } \\
\text { Desmit and Hart (1966) } \\
\text { Hitzig et al. (1968) } \\
\text { Sharpstone et al. (1968) } \\
\text { Moncrieff and Glasgow (1970) } \\
\text { Kibel and Barnard (1964) } \\
\text { Künzer and Aalam (1964) } \\
\text { Piel and Phibbs (1966) }\end{array}$ & $\begin{array}{c}160(1 / 26) \\
<200(1 / 10) \\
460 \\
540 \\
128 \\
\text { Normal } \\
88 \text { before heparin } \\
370 \text { after heparin } \\
\text { Low } \\
- \\
-\end{array}$ & $\begin{array}{l}<55(6 / 26) \\
<50(0 / 10) \\
148 \\
220 \\
100 \\
- \\
- \\
= \\
- \\
-\end{array}$ & $\begin{array}{l}<50(3 / 26) \\
<75(0 / 11) \\
300 \\
500 \\
300 \\
160 \\
- \\
- \\
-\end{array}$ & $\begin{array}{c}+(7 / 26) \\
+(5 / 5) \\
+(1 / 2) \\
+ \\
+ \\
+512 \mu \mathrm{gl}) \\
+ \\
+(1 / 2) \\
+(2 / 2) \\
-\end{array}$ & $\begin{array}{c}- \\
+(2 / 2) \\
\text { (Spontaneous) } \\
+ \\
+ \\
+ \\
+(2 / 2) \\
+(3 / 3) \\
+(5 / 5)\end{array}$ \\
\hline
\end{tabular}

^Pathologically high levels of fibrinogen, factor V, and factor VIII were frequent in these series.

Note: Fractions (e.g. 1/26) indicate the number of patients of the series showing the abnormality in question. 
investigations performed at varying times from diagnosis failed to show a consumptive coagulopathy but FDPs were raised in the 5 cases tested. Our Case 4 appears to be similar to the patients in this series.

The most extensive coagulation investigation so far reported in this disease is that by Sanchez Avalos et al. (1970). Multiple factors were assayed at 5 to 7 day intervals, starting 6 or more days after the onset of the disease. Though they found no evidence of consumptive coagulopathy at that stage of the disease, thrombocytopenia, the longer lasting abnormality after DIC, was initially present in every patient. This was often associated with abnormally high levels of fibrinogen and factor VIII consistent with a 'rebound' phenomenon after DIC. In 3 patients these authors observed 'recurrent episodes of acute intravascular consumption'. These were seen only in children with an extremely severe and sometimes fatal course. Sequential coagulation data were shown for one case where there was a 'wave' of consumption of both platelets and coagulation factors developing between 2 and 3 weeks from the onset of symptoms. These authors therefore appear to have recorded the same changes as in our Cases 2 and 3, but at a later stage of the disease rather than at presentation. It is continuing or recurrent intravascular coagulation that justifies the trial of anticoagulants in this disease. This appears to have occurred in our Case 1 as well as in the 3 patients of Sanchez Avalos et al. (1970). These coagulation studies indicate the severity and reversible nature of the intravascular coagulation but are unable to define whether this is truly disseminated (i.e. DIC) or localized to the kidney.

We gratefully acknowledge the co-operation of Professors J. H. Hutchison and G. C. Arneil, and Drs. R. A. Shanks and D. H. Wallace under whose clinical care these patients were being treated, and of the numerous nursing staff involved with the patients' care.

\section{REFERENCES}

Alkjaersig, N., Fletcher, A. P., and Sherry, S. (1959). E-aminocaproic acid: an inhibitor of plasminogen activation. fournal of Biological Chemistry, 234, 832.

Baker, L. R. I., Rubenberg, M. L., Dacie, J. V., and Brain, M. C. (1968). Fibrinogen catabolism in microangiopathic haemolytic anaemia. British fournal of Haematology, 14, 617.

Brain, M. C. (1969). The haemolytic-uremic syndrome. Seminars in Hematology, 6, 162.

Brain, M. C., Baker, L. R. I., McBride, J. A., Rubenberg, M. L., and Dacie, J. V. (1968). Treatment of patients with microangiopathic haemolytic anaemia with heparin. British fournal of Haematology, 15, 603.
Brain, M. C., Dacie, J. V., and Hourihane, D. O'B. (1962). Microangiopathic haemolytic anaemia: the possible role of vascular lesions in pathogenesis. British fournal of Haematology, 8, 358.

Brain, M. C., and Hourihane, D. O'B. (1967). Microangiopathic haemolytic anaemia: the occurrence of haemolysis in experimentally produced vascular disease. British fournal of Haematology, 13, 135.

Brecher, G., and Cronkite, E. P. (1950). Morphology and enumeration of human blood platelets. Fournal of Applied Physiology, $3,365$.

Bull, B. S., Rubenberg, M. L., Dacie, J. V., and Brain, M. C. (1968) Microangiopathic haemolytic anaemia: mechanisms of red-cell fragmentation: in vitro studies. British fournal of Haematology, $14,643$.

Corrigan, J. J., Jr., Ray, W. L., and May, N. (1968). Changes in the blood coagulation system associated with septicemia. New England fournal of Medicine, $279,851$.

Dacie, J. V., and Lewis, S. M. (1963). Practical Haematology, 3rd ed. Churchill, London.

Desmit, E. M., and Hart, H. C. (1966). Behandeling van het hemolytisch-uremisch syndroom. Nederlandsch Tijdschrift voor Geneeskunde, 110, 355.

Deykin, D. (1970). The clinical challenge of disseminated intravascular coagulation. New England fournal of Medicine, 283, 636.

Gilchrist, G. S., Lieberman, E., Ekert, H., Fine, R. N., and Grushkin, C. (1969). Heparin therapy in the haemolyticuraemic syndrome. Lancet, $1,1123$.

Hammond, D., and Lieberman, E. (1970). The hemolytic uremic syndrome. Archives of Internal Medicine, 126, 816.

Hardisty, R. M., and MacPherson, J. C. (1962). A one-stage factor VIII assay and its use on venous and capillary plasma. Thrombosis et diathesis Haemorrhagica, 7, 215.

Hathaway, W. E. (1970). Care of the critically ill child: the problem of disseminated intravascular coagulation. Pediatrics, 46, 767.

Hitzig, W. H., Straub, P. W., Lo, S. S., and Frick, P. G. (1968). Clinical experience with anticoagulant therapy in the management of disseminated intravascular coagulation in children. Proceedings of the Royal Society of Medicine, 61, 1138.

Katz, J., Lurie, A., Kaplan, B. S., Krawitz, S., and Metz, J. (1971). Coagulation findings in the hemolytic-uremic syndrome of infancy: similarity to hyperacute renal allograft rejection. Fournal of Pediatrics, 78, 426.

Kibel, M. A., and Barnard, P. J. (1964). Treatment of acute haemolytic-uraemic syndrome with heparin. (Letter.) Lancet, 2, 259.

Künzer, W., and Aalam, F. (1964). Treatment of the acute haemolytic-uraemic syndrome with heparin. (Letter.) Lancet, 1, 1106.

Lanzkowsky, P., and McCrory, W. (1967). Disseminated intravascular coagulation as a possible factor in the pathogenesis of thrombotic microangiopathy (hemolytic-uremic syndrome). fournal of Pediatrics, 70, 460.

Merskey, C., Kleiner, G. J.. and Johnson, A. J. (1966). Quantitative estimation of split products of fibrinogen in human serum: relation to diagnosis and treatment. Blood, 28, 1 .

Moncrieff, M. W., and Glasgow, E. F. (1970). Haemolytic-uraemic syndrome treated with heparin. British Medical fournal, 3, 188,

Monnens, L., and Schretlen, E. (1967). Intravascular coagulation in an infant with the hemolytic-uremic syndrome. Acta Paediatrica Scandinavica, 56, 436.

Piel, C. F., and Phibbs, R. H. (1966). The hemolytic-uremic syndrome. Pediatric Clinics of North America, 13, 295.

Rubenberg, M. L., Regoeczi, E., Bull, B. S., Dacie, J. V., and Brain, M. C. (1968). Microangiopathic haemolytic anaemia: the experimental production of haemolysis and red-cell fragmentation by defibrination in vivo. British fournal of Haematology, 14, 627.

Sanchez Avalos, J., Vitacco, M., Molinas, F., Peñalver, J., and Gianantonio, C. (1970). Coagulation studies in the hemolyticuremic syndrome. Fournal of Pediatrics, 76, 538.

Sharpstone, P., Evans, R. G., O'Shea, M., Alexander, L., and Lee, H. A. (1968). Haemolytic-uraemic syndrome: survival after prolonged oliguria. Archives of Disease in Childhood, 43, 711. 
Stefanini, M. (1950). New one-stage procedures for the quantitative determination of prothrombin and labile factor. American fournal of Clinical Pathology, 20, 233.

Uttley, W. S. (1970). Serum levels of fibrin/fibrinogen degradation products in the haemolytic-uraemic syndrome. Archives of Disease in Childhood, 45, 587.

\section{Addendum}

Since submitting this paper a fifth patient with HUS has been investigated. The initial platelet count was
$95,000 / \mathrm{mm}^{3}$, fibrinogen $172 \mathrm{mg} / 100 \mathrm{ml}$, and FDPs $80 \mu \mathrm{g} / \mathrm{ml}$. Factor $\mathrm{V}$ was $130 \%$. During heparinization the platelets and fibrinogen rose to normal, the FDPs fell to normal and the factor V rose to $220 \%$. Urine flow returned after 5 days on heparin. The severity of the coagulation defect appeared to be similar to that in Case 1 described above, but the patient has survived.

Correspondence to Dr. M. L. N. Willoughby, Royal Hospital for Sick Children, Yorkhill, Glasgow C3. 